\title{
EFEK ANTIHIPERGLIKEMIK KOMBINASI EKSTRAK ETANOL DAUN MENGKUDU (MORINDA CITRIFOLIA L) DAN DAUN JAMBU BIJI (PSIDIUM GUAJAVA L) PADA TIKUS PUTIH (RATTUS NORVEGICUS) YANG DIINDUKSI ALOKSAN
}

\author{
Amila Rahmah, Arsyik Ibrahim, Dewi Rahmawati \\ Laboratorium Penelitian dan Pengembangan FARMAKA TROPIS, Fakultas Farmasi, \\ Universitas Mulawarman, Samarinda, Kalimantan Timur \\ email:amilarahmahh@gmail.com
}

\begin{abstract}
A study to observe the antihiperglicemic activity of combination of ethanol extract of Noni (mengkudu) leaves and ethanol extract of guava leaves had been done. The research was conducted in order to determine the antihyperglycemic activity of combination of ethanol extract of Noni leaves and ethanol extract of guava leaves in albino rats. This research is an experimental study and use 12 albino rats induced with alloxan $120 \mathrm{mg} / \mathrm{kgBW}$ intraperitoneally .The rats were divided into 4 groups, negative control groups (aquadest), positive control group (Glybenclamid) and 2 test group was given the combination of ethanol extract of noni leaves and ethanol extract of guava leaves with 2 comparison doses (2:1 and 1:2). The blood glucose level of albino rats measured on the first day before induced by alloxan which fasted for 16 hours, the blood glucose measured by glucometer. After the blood glucose increased, the rats have the treatment for 7 days. The result of Two-way ANAVA showed have the activity of all group, so proceed with BNJD test. The result showed that combination of ethanol extract of Noni (mengkudu) leaves and ethanol extract of guava leaves comparison dose 1:2 and 2:1 have effect in decreasing blood glucose level on albino rats
\end{abstract}

keywords: Noni leaves, Guava leaves, Antihyperglycemic, Albino rat.

\begin{abstract}
Abstrak
Telah dilakukan penelitian mengenai efek antihiperglikemik dari. Penelitian ini bertujuan untuk mengetahui aktivitas antihiperglikemik kombinasi ekstrak etanol daun mengkudu (Morinda citrifolia Linn) dan daun jambu biji (Psidium guajava Linn) pada tikus putih. Desain penelitian ini adalah desain eksperimental dengan menggunakan tikus putih sebanyak 12 ekor yang diinduksi aloksan secara intraperitoneal dengan dosis $120 \mathrm{mg} /$ KgBB. Tikus dibagi menjadi empat kelompok, antara lain kelompok kontrol negatif (aquades), kelompok kontrol positif (Glibenklamid), dan dua kelompok uji diberikan kombinasi ekstrak etanol daun mengkudu dan daun jambu biji dengan dua perbandingan dosis (2:1 dan 1:2). Pengukuran kadar glukosa darah tikus putih dilakukan pada hari ke-1 sebelum diinduksi aloksan yang sebelumnya dipuasakan terlebih dahulu selama 16 jam. Setelah diinduksikan aloksan, kemudian diukur kadar glukosa darah tikus dengan glukometer. Setelah mengalami peningkatan glukosa darah, hewan uji diberi perlakuan selama 7 hari. Berdasarkan uji ANAVA dua arah menunjukkan bahwa glibenklamid dan kombinasi ekstrak etanol daun mengkudu dan daun jambu biji memberikan hasil yang signifikan sehingga dilakukan uji lanjutan yaitu uji Beda Nyata Jujur Duncan. Hasil
\end{abstract}


penelitian menunjukkan bahwa kombinasi ekstrak etanol daun mengkudu dan daun jambu biji dengan perbandingan dosis 1:2 dan 2:1 memiliki efek menurunkan kadar glukosa darah pada tikus putih.

Kata kunci :Daun mengkudu.,Daun Jambu Biji, Antihiperglikemik, Tikus Putih.

\section{PENDAHULUAN}

Diabetes mellitus adalah suatu kelompok penyakit metabolik dengan karakteristik hiperglikemia yang terjadi karena kelainan sekresi insulin, kerja insulin atau kedua-duanya, yang berhubungan dengan kerusakan jangka panjang, disfungsi atau kegagalan beberapa organ tubuh, terutama mata, ginjal, saraf, jantung dan pembuluh darah (Gustaviani, 2007).

Mengkudu (Morinda citrifolia Linn) telah digunakan sebagai pengobatan selama 2000 tahun lebih. Tanaman mengkudu sekarang dipublikasikan oleh insan kesehatan sebagai obat ajaib dalam pengobatan berbagai penyakit seperti diabetes mellitus, hepatitis kronis, gangguan fungsi ginjal, kencing batu, dan gangguan hormon tiroid (Kirtishanti, 2008). Mengkudu memiliki kelebihan karena memiliki fungsi konstruktif, yaitu membangun kembali jaringan-jaringan yang rusak, menyembuhkan penyakit komplikasi lain, menurunkan kadar gula darah dan mengembalikan kemampuan tubuh untuk mengatur gula darah seperti sediakala (Kirtishanti, 2008). Daun mengkudu mengandung zat-zat aktif seperti etil kaprilat, glukopiranosa, flavonoid, proxeronin dan xeronin. Xeronin diketahui dapat meningkatkan protein GLUT 4 yang berhubungan dengan Diabetes Mellitus. GLUT 4 (transporter glukosa 4) adalah protein transpor untuk glukosa yang bertujuan membawa glukosa masuk ke dalam sel. Flavonoid bekerja dalam menghambat enzim alfa-glucosidase di dalam saluran cerna, akibatnya daya absorbsi karbohidrat berkurang sehingga menurunkan glikemik dan menciptakan efek hemat insulin (Evacuasinasy, 2010).

Tanaman herbal lainnya yang memiliki efek antidiabetik adalah jambu biji (Psidium guajava Linn). Ekstrak air daun jambu biji memiliki efek hipoglikemik. Kandungan terpenting pada ekstrak etanol daun jambu biji sebagai antidiabetik adalah tannin dan polifenol yang merupakan antioksidan yang dapat meningkatkan konsentrasi insulin dalam plasma (Ojewole, 2005).

Menurut penelitian yang dilakukan sebelumnya menyebutkan bahwa ekstrak etanol daun mengkudu (Morinda citrifolia L) berpotensi dalam penurunan kadar glukosa darah pada mencit yang diinduksi aloksan dengan dosis 1,6 g/KgBB setara dengan glibenklamid. Selain itu penelitian lain menyebutkan bahwa ekstrak etanol daun jambu biji (Psidium guajava L) dengan dosis $500 \mathrm{mg} / \mathrm{KgBB}$ memberikan efek penurunan kadar glukosa darah (Evacuasiany, 2010; Rapaka, 2012)

Berdasarkan uraian diatas, telah dilakukan penelitian mengenai pengaruh pemberian kombinasi ektrak etanol daun mengkudu (Morinda citrifolia Linn) dan daun jambu biji (Psidium guajava Linn) dalam penurunan kadar glukosa darah pada tikus putih (Rattus Novergicus) yang diinduksi aloksan.

\section{METODE PENELITIAN}

\section{Bahan}

Bahan yang diteliti adalah daun mengkudu, daun jambu biji, pelarut etanol 96\%, $\mathrm{NaCl}$ 0,9\%, aloksan, aquadest, Glibenklamid, Strip glukosa, Na CMC. 


\section{Peralatan}

Peralatan yang digunakan dalam penelitian ini antara lain timbangan digital, seperangkat alat ekstraksi, labu takar, batang pengaduk, rotary evaporator, water bath, gelas kimia, glukometer easytouch, mortir dan stamper, spoid dan sonde serta alat penunjang lainnya.

\section{Pengambilan Sampel}

Sampel yang digunakan pada penelitian ini adalah daun mengkudu (Morinda citrifolia L) dan daun jambu biji (Psidium guajava L). Pengambilan sampel di Kelurahan Teritip Kecamatan Balikpapan Timur. ). Sampel yang digunakan yaitu daun yang masih segar, baik daun tua maupun muda namun pucuk daun tidak termasuk daun yang diambil. Sampel yang telah terkumpul dicuci bersih selanjutnya dilakukan sortasi basah. Pengeringan dilakukan untuk mengurangi kadar air dengan cara dianginkan atau tidak dipanaskan dengan sinar matahari langsung. Sortasi kering dilakukan untuk memilih sampel yang telah kering bebas dari kotoran dan kerusakan. Setelah itu dilakukan perajangan untuk memperluas permukaan daun mengkudu dan daun jambu biji untuk meningkatkan kontak antara cairan pelarut dengan simplisia.

\section{Prosedur Ekstraksi}

Simplisia dimasukkan ke dalam bejana maserasi dan dimaserasi menggunakan pelarut etanol 96\%. Proses ekstraksi dengan metode maserasi berlangsung selama kurang lebih 3-4 hari. Maserat (hasil maserasi) disaring menggunakan kertas saring dan ditampung ke dalam wadah. Maserat kemudian dipekatkan menggunakan rotary evaporator dan dilanjutkan dengan penguapan di atas waterbath hingga diperoleh ekstrak etanol kental.

\section{Prosedur Pengujian}

Tikus dikelompokkan ke dalam 4 kelompok, yaitu kelompok kontrol negatif (aquadest), kelompok kontrol positif (Glibenklamid dosis 5mg), dan kelompok bahan uji (perbandingan dosis 2:1 dan 1:2 ekstrak etanol daun mengkudu dan daun jambu biji). Tikus putih yang telah dipersiapkan untuk penelitian akan dipuasakan dari makanan selama 16 jam dengan tetap diberi air minum.

Sebelum pengujian, masing-masing hewan ditimbang berat badannya, setelah itu dilakukan pengukuran kadar glukosa awal tikus dengan cara memotong ujung ekor tikus dan meneteskan darah tikus pada strip glukosa yang telah terpasang pada alat glukometer. Setelah itu, tikus diinduksikan aloksan secara intraperitoneal dengan dosis $120 \mathrm{mg} / \mathrm{KgBB}$ untuk meningkatkan kadar glukosa darah hewan uji. 1 hari setelah diinduksikan aloksan, kembali diukur kadar glukosa darah tikus, jika kadarnya telah mengalami peningkatan, maka masing-masing tikus diberi larutan uji secara oral berdasarkan kelompoknya, dimana pemberian larutan ekstrak dilakukan selama 7 hari setiap hari. Pengukuran kadar glukosa dilakukan setiap hari sebelum pemberian larutan uji dilakukan.

\section{HASIL DAN PEMBAHASAN}

Pengujian efek antihiperglikemik kombinasi ekstrak etanol daun mengkudu dan daun jambu biji bertujuan untuk mengetahui adanya kemampuan kombinasi kedua ekstrak tersebut dalam penurunan kadar glukosa darah. Berikut merupakan hasil rata-rata penurunan kadar glukosa darah tikus yang diukur selama 7 hari.

Untuk mengetahui adanya aktivitas dari kombinasi ekstrak etanol daun mengkudu dan daun jambu biji terhadap penurunan kadar glukosa darah,maka data yang digunakan adalah penurunan kadar glukosa darah pada hari ke-2 hingga hari ke-8 pada setiap kelompok. Rata-rata penurunan kadar glukosa darah menunjukkan bahwa kontrol positif dan kombinasi dari kedua ekstrak tersebut memiliki aktivitas dalam penurunan kadar glukosa darah. Berdasarkan uji anava dua arah pada Tabel 1 pada tingkat kepercayaan 95\% 
dan 99\% menunjukkan hasil yang signifikan dimana Fhitung > Ftabel, pada sumber varian konsentrasi uji. Kemudian dilakukan uji lanjutan berdasarkan nilai koefisien keseragaman (KK) yaitu uji Beda Nyata Jujur Duncan.

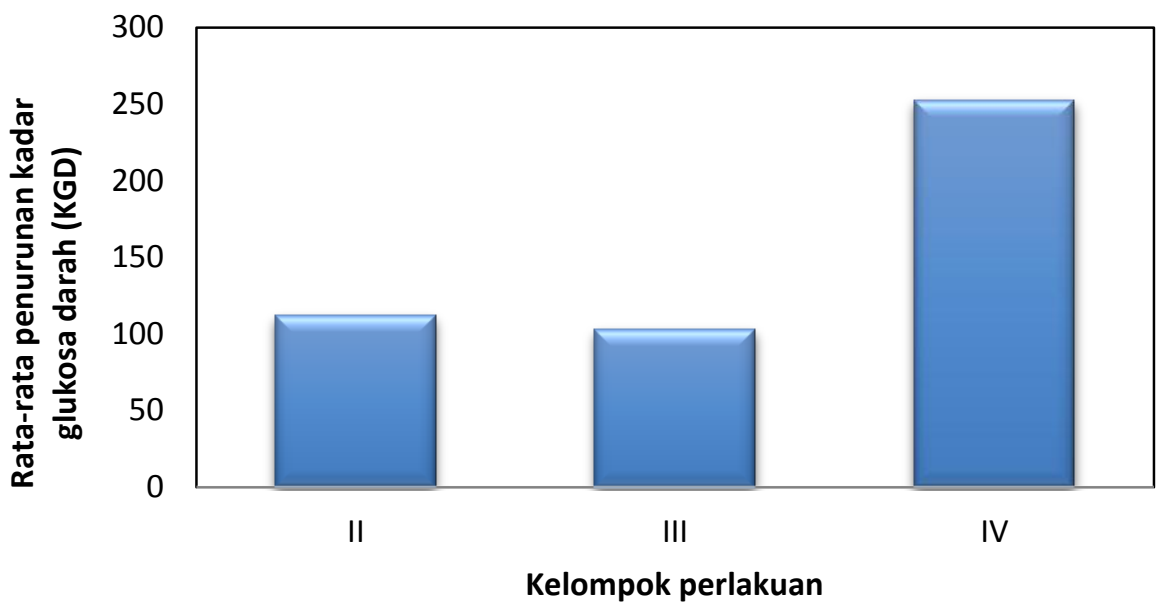

Gambar 1. Grafik laju penurunan kadar glukosa darah pada masing -masing kelompok setiap hari setelah perlakuan. Keterangan: Klp II= kelompok kontrol positif (glibenklamid), Klp III = Ekstrak etanol daun mengkudu dan daun jambu biji (2:1), Klp IV = Ekstrak etanol daun mengkudu dan daun jambu biji (1:2 )

Tabel 1.Hasil analisis Anova Dua Arah

\begin{tabular}{|l|r|r|r|r|r|r|}
\hline \multirow{2}{*}{$\begin{array}{c}\text { Sumber } \\
\text { variansi }\end{array}$} & Db & \multicolumn{1}{c|}{$\mathrm{Jk}$} & \multicolumn{2}{c|}{ Kt } & \multirow{2}{*}{ Fhitung } & \multicolumn{2}{c|}{ Ftabel } \\
\cline { 6 - 8 } & & & & & $5 \%$ & $1 \%$ \\
\hline Konsentrasi uji & 2 & 295651.5 & 147825.8 & 2.4 & 2.32 & 5.15 \\
\hline Waktu & 6 & 618845.1 & 103140.9 & 1.676 & 2.32 & 3.26 \\
\hline Interaksi & 12 & 301161 & 25096.75 & 0.407 & 1.99 & 2.64 \\
\hline Galat & 42 & 2584191 & 61528.36 & & & \\
\hline Total & 62 & 3799848 & & & & \\
\hline
\end{tabular}

Tabel 2. Perbedaan Nilai Rerata Penurunan Kadar Glukosa Darah Hewan Uji antar Kelompok dari Hasil Uji BNJD

\begin{tabular}{|c|c|c|c|c|c|}
\hline No. & Perlakuan & Rerata & $\begin{array}{l}\text { Glibenklamid } \\
(|167.429|)\end{array}$ & $\begin{array}{c}\mathbf{2 : 1} \\
(|195.429|)\end{array}$ & $\begin{array}{c}\mathbf{1 : 2} \\
(253.857)\end{array}$ \\
\hline 1 & Glibenklamid & $(|167.429|)$ & - & - & - \\
\hline 2 & $2: 1$ & $(|195.429|)$ & 28 & - & - \\
\hline 3 & $1: 2$ & 253.857 & 86.43 & 58.428 & - \\
\hline \multicolumn{3}{|r|}{$\mathrm{P}(0,05.42)$} & 2.858 & 3.005 & 3.102 \\
\hline \multicolumn{3}{|c|}{ BNJD 0,05 (P.Sý) } & 334.392 & 351.359788 & 236.308 \\
\hline \multirow{2}{*}{\multicolumn{3}{|c|}{$\begin{array}{r}\mathrm{P}(0,01.42) \\
\text { BNJD } 0,01 \text { (P.Sý) }\end{array}$}} & 3.825 & 3.988 & 4.098 \\
\hline & & & 316.2625 & 329.7398 & 338.8349 \\
\hline
\end{tabular}


Hasil uji lanjutan BNJD pada Tabel 2 menunjukkan bahwa antara kelompok kombinasi ekstrak etanol daun mengkudu dan daun jambu biji 2:1, 1:2 dan kontrol positif tidak terdapat perbedaan bermakna. Akan tetapi, dilihat pada rerata penurunan kadar glukosa darah pada kelompok uji kombinasi ekstrak etanol daun mengkudu dan daun jambu biji 1:2 lebih baik dibandingkan kelompok uji kombinasi ekstrak etanol daun mengkudu dan daun jambu biji 2:1 dan kelompok kontrol positif. Jadi, disimpulkan bahwa kombinasi ekstrak etanol daun mengkudu dan daun jambu biji 1:2 lebih efektif dibandingkan 2:1 dalam hal penurunan kadar glukosa darah hewan uji yang diinduksi aloksan.

Adanya penurunan kadar glukosa darah pada hewan uji yang mengalami hiperglikemik yang diberi kombinasi ekstrak etanol daun mengkudu dan daun jambu biji dikarenakan adanya kandungan flavonoid dan xeronin pada daun mengkudu. Diketahui bahwa senyawa xeronin dapat meningkatkan protein GLUT 4 (transporter glukosa 4) yang merupakan protein transpor untuk glukosa yang bertujuan membawa glukosa masuk ke dalam sel. Flavonoid bekerja dalam menghambat enzim alfa-glucosidase di dalam saluran cerna, akibatnya daya absorbsi karbohidrat berkurang sehingga menurunkan glikemik dan menciptakan efek hemat insulin. Sedangkan senyawa yang berpotensi sebagai antidiabetes pada daun jambu biji adalah tannin dan polifenol yang merupakan antioksidan yang dapat meningkatkan konsentrasi insulin dalam plasma.

\section{KESIMPULAN}

Kombinasi ekstrak etanol daun mengkudu dan daun jambu biji dengan perbandingan 1:2 dan 2:1 serta kontrol positif memberikan aktivitas penurunan kadar glukosa darah namun ketiga kelompok uji tersebut tidak memberikan perbedaan yang bermakna dalam penurunan kadar glukosa darah.

\section{DAFTAR PUSTAKA}

1. Evacuasiany, Endang. 2010. Efek Ekstrak Etanol Daun Mengkudu (Morinda citrifolia L.) terhadap Kadar Glukosa Darah Mencit Jantan Galur Swiss Webster yang Diinduksi Aloksan. Jurnal Medika Planta. Vol. 10 No 1

2. Gustaviani R. 2006. Definisi dan Klasifikasi Diabets Melitus. Buku Ajar Ilmu Penyakit Dalam Edisi III. Balai Penerbit FKUI : Jakarta.

3. Kirtishanti, Aguslina, Ryanto Budiono, Ratih, dan Fitria Isfandiari. 2008. Efek Ekstrak Daun Mengkudu (Morinda citrifolia L) terhadap Jumlah Protein GLUT4 pada Tikus Putih Hiperglikemik. Jurnal Farmasi Indonesia Vol. 4 No. 2

4. Ojewole JA. 2005. Hypoglicemic and Hipotensive Effect of Psidium guajava Linn (Myrtaceae) Leaf Aqueous Extract. Method Find Exp Clin Pharmacol Vol. 27 No.10

5. Rapaka, Deepthi and SrinivasaRao Vennam. 2012. Evaluation and Comparison of Antidiabetic Activity of Hydroalcoholic Extracs of Fresh and Dry Leaves of Psidium guajava in type-II Diabetes Mellitus. International Research Journal of Pharmaceutical and Applied Sciences Vol.2 No.4 